\title{
Removal of Heavy Metals from Aqueous Solution by Using Low Cost Rice Husk in Batch and Continuous Fluidized Experiments
}

\author{
Jabbar H. Al-Baidhani and Simaa T. Al-Salihy
}

\begin{abstract}
This study aims to evaluate the performance efficiency of the proposed adsorbent (rice husk). The adsorptive capacity and removal efficiency of the rice husk were evaluated for the removal of heavy metals of $(\mathrm{Cd}, \mathrm{Pb}$ and $\mathrm{Cr}$ ) from aqueous solutions. The results showed the following removal efficiencies: (97.96\% for $\mathrm{Cd}, \mathbf{9 0 \%}$ for $\mathrm{Pb}$, and $\mathbf{8 4 \%}$ for $\mathrm{Cr}$ ). Adsorbent loading capacities for cadmium determined by batch studies were verified through continuous column experiments (fluidized bed). It was found that the maximum adsorption capacity of the candidate adsorbent $(5.54) \mathrm{mg} / \mathrm{g}$ in Cd batch system. A set of equilibrium isothermal experiments were conducted and fitted with two models; Langmuir and Freundlich. The equilibrium isotherms of rice husk were found to be of a favorable type and Freundlich isotherm model gave the best fit to represent the experimental data of this system with correlation coefficient equals to 0.9934. Eleven continuous experiments were carried out in fluidized bed column to study the effect of initial concentrations, bed depth and flow rate on the performance of adsorption process. Also it was made a comparison between the efficiency of the rice husk adsorbent in removing of $\mathrm{Cd}(\mathrm{II})$ with the well-known adsorbent of activated carbon in continuous fluidized bed process. The results proved that the rice husk to be an efficient and economic adsorbent for the removal of different heavy metals from wastewater.
\end{abstract}

Index Terms-Heavy metals, adsorption, rice husk, batch experiment, continuous fluidized bed experiments.

\section{INTRODUCTION}

Fresh water is already a limiting resource in many parts of the world. In the next century, it will become even more limiting due to increased population, urbanization, and climate change, thus leading to water crisis and serious consequences on the environment. This limitation is caused not just by increased demand for water, but also by pollution in freshwater ecosystems.

Heavy metals ions are detected in the waste streams from different industrial activities such as mining operations, tanneries, electronics, electroplating, petroleum refineries, and petrochemical industries [1].

The major advantages of adsorption over conventional treatment methods include: low-cost; high efficiency; minimization of chemical sludge; regeneration of biosorbent

Manuscript received February 5, 2015; revised April 25, 2015. This work was supported in part by College of Engineering of Babylon University, Iraq. Jabbar H. Al-Baidhani and Simaa T. Al-Salihy thank College of Engineering of Babylon University, Iraq for financial support.

Jabbar H. Al-Baidhani is with College of Engineering, Babylon University, Iraq (e-mail: jabbaralbaidhani@yahoo.com).

Simaa T. Al-Salihy is with College of Environment Science, University of Al-Qasim Green, Babylon, Iraq (e-mail: simaa.alsalihy@yahoo.com). and possibility of metal recovery [2]. In recent years, special attention has been focused on the use of natural adsorbents as an alternative to replace the conventional adsorbents. Natural materials that are available in large quantities or certain waste from agricultural operations may have the potential to be used as low cost adsorbents as they represent solid waste, widely available and are environmentally friendly after using them. Natural materials such as rice husk that are available in large quantities, or certain waste products from industrial or agricultural operations, may have potential as inexpensive sorbents [3], [4].

It was possible to use grounded rice hull as adsorbent material. Aqueous solutions of various methylene blue dye concentration (5-25 $\mathrm{mg} \mathrm{l}^{-1)}$ were shaken with certain amount of adsorbents to determine the adsorption capacity. Both treated and untreated rice hulls were used for methylene blue adsorption. Maximum dye was sequestered from the solution within 60-90 min after the beginning of every experiment The adsorption capacity increased from 72 to $94 \%$ with increasing the $\mathrm{pH}$ from 3 to 10 . Pretreatment of rice hulls with citric acid did not reveal any beneficial effect [5].

There was a study dealing with using of less expensive adsorbents and their utilization possibilities for agricultural waste by-products such as rice husk, for the elimination of phenol from aqueous solution. Experiments have been conducted to examine the liquid-phase adsorption of phenol from aqueous solution by rice husk $\mathrm{RH}$ and activated rice husk ARH (pretreated by $13 \mathrm{M} \mathrm{H}_{2} \mathrm{SO}_{4}$ with $0.5 \mathrm{NaOH}$ and thermally treated at $573 \mathrm{k}$ ). The data fits well to both the Langmuir and Freundish isotherm models indicating favorable and monolayer adsorption [6].

It can be showed that the percent removal of lead is improved with the increasing in the bed height of granular activated carbon in the fluidized bed. The removal efficiency of the metal concentration from solution increases as the bed height increases since the length of the bed through which the solution increases. Since in fluidization the bed is constantly moving which results in maximum exposure of GAC adsorbent to the solution. Thus, even at less quantity of bed mass maximum amount of removal efficiency can be obtained [7].

Investigation was conducted with batch sorption of lead $(\mathrm{Pb})$ on to activated carbon from coconut $(\mathrm{CA})$ and seed hull of the palm tree (GA). It could be best fitted by the Langmuir and Freundlich isotherms. From the first, the equilibrium sorption capacities of lead ion were determined and found to be respectively 4.38 and $3.77 \mathrm{mg} / \mathrm{g}$ for $\mathrm{CA}$ and $\mathrm{GA}$ at $60 \mathrm{C}^{\circ}$. The maximum adsorptions were obtained at $60 \mathrm{C}^{\circ}, \mathrm{pH} 4$ and with a $\mathrm{Pb}$ initial concentration of $100 \mathrm{mg} / \mathrm{l}$ [8]. 


\section{MATERIALS AND METHODS}

\section{A. Adsorbate Material}

Heavy metals was chosen in this study because of its long recognized as eco-toxicological hazardous substances, and their chronic toxicities and accumulation abilities in living organisms have been of great interest for many years [9]. The heavy metals were tested in the present study are cadmium $(\mathrm{Cd})$, lead $(\mathrm{Pb})$ and chromium $(\mathrm{Cr})$.

\section{B. Adsorbent Material}

Rice husk was crushed, sieved and stored in plastic bags by size. Then, husks were thoroughly washed at several times with distilled water to remove impurities and dried by exposure to the sun light for $12 \mathrm{hr}$. The dried husks were stored in desiccators until used [10]. Physical properties of rice husk are reported in Table I.

TABLE I: PHYSICAL CHARACTERISTICS OF RICE HUSK

\begin{tabular}{|c|c|}
\hline Bulk density $\left(\mathrm{Kg} / \mathrm{m}^{3}\right)$ & $0.2197 \times 10^{3}$ \\
\hline Solid density $\left(\mathrm{Kg} / \mathrm{m}^{3}\right)$ base dry & $1.48 \times 10^{3}$ \\
\hline Surface Area $\left(\mathrm{m}^{2} / \mathrm{g}\right)$ & 97.5 \\
\hline
\end{tabular}

\section{Preparation of the Stock Solution}

Synthetic stock solutions of cadimuim, and lead were prepared using their nitrate salts, $\mathrm{Cd}\left(\mathrm{NO}_{3}\right)_{2} \cdot 4 \mathrm{H}_{2} \mathrm{O}$, $\mathrm{Pb}\left(\mathrm{NO}_{3}\right)_{2} \cdot 2 \mathrm{H}_{2} \mathrm{O}$ respectively, in distilled water. The stock solution of $\mathrm{Cr}(\mathrm{VI})$ was prepared using potassium dichromate $\left(\mathrm{K}_{2} \mathrm{Cr}_{2} \mathrm{O}_{7}\right)$. All working solutions were prepared by diluting the stock solutions with distilled water to the desired concentration of $25 \mathrm{mg} / \mathrm{l}$. The experiment was done with synthetic solutions $\mathrm{pH}$ of 6 based on the recommendation of [10]. Adsorption experiments were carried out at temperature of $25 \pm 5 \mathrm{C}^{\circ}$.

\section{Experimental Procedure for Batch Experiments}

The batch sorption experiment conducted by varying the mass of adsorbent. The experiments were carried out in 250 $\mathrm{ml}$ Erlenmeyer flasks and the total volume of the reaction mixture was kept at $100 \mathrm{ml}$. The $\mathrm{pH}$ of solution was maintained at a desired value by adding $\mathrm{NaOH}$ or HCL. Portions of the solution with $25 \mathrm{mg} / \mathrm{l}$ initial concentration was placed in 5 bottles, containing accurately rice husk ranging in weight $(0.25,0.5,1,2$, and 3$) \mathrm{g}$ with the particle size of $(0.6-1.2) \mathrm{mm}$. Then the bottles placed on a shaker and agitated at $150 \mathrm{rpm}$ continuously for 3 hours. At this point the concentration is in equilibrium. The flasks were withdrawn and the reaction mixtures were filtered through (Wattman 42) filters to remove any suspended adsorbent. All batch experiments were conducted at constant temperature $(25 \pm 5$ $\left.C^{\circ}\right)$. Initial and final concentrations of metals were determined by atomic absorption spectrophotometer (AAS). The percentage of removal of heavy metals adsorption by the adsorbents was computed by using the following equation:

$$
\% \text { Adsorption } \frac{C_{\circ}-C_{e}}{C_{\circ}} \times 100
$$

The results are given in Table II to IV. The adsorbed amount is then calculated by the following equation:

$$
q_{e}=\frac{V\left(C_{\mathrm{o}}-C_{e}\right)}{W}
$$

where $C_{\mathrm{o}}$ and $C_{e}$ are the initial and equilibrium concentrations of each metal $(\mathrm{mg} / \mathrm{l})$ in the solution. $V$ is the volume of the solution $(L)$ and $W$ is the mass of dry adsorbent used (gm).

\section{RESULTS AND DISCUSSION}

\section{A. Equilibrium Isotherm Rice Husk}

TABLE II: EQUILIBRIUM ISOTHERM FOR RICE HUSK AT CD (II) CONCENTRATION $\left(C_{0}=25 \mathrm{MG} / \mathrm{L}\right), \mathrm{PH}=6$

\begin{tabular}{|c|c|c|c||}
\hline$W(\mathrm{~g})$ & $C e(\mathrm{mg} / \mathrm{l})$ & $q e(\mathrm{mg} / \mathrm{g})$ & Removal \% \\
\hline 0.25 & 11.15 & 5.54 & 55.40 \\
\hdashline 0.5 & 5.94 & 3.81 & 76.24 \\
\hdashline 1 & 2.73 & 2.22 & 89.0. \\
\hline 2 & 1.20 & 1.19 & 99.20 \\
\hdashline 3 & 0.51 & 0.81 & 97.96 \\
\hline \hline
\end{tabular}

TABLE III: EQUILIBRIUM ISOTHERM FOR RICE HUSK AT PB(II) CONCENTRATION $\left(C_{\mathrm{o}}=25 \mathrm{MG} / \mathrm{L}\right), \mathrm{PH}=6$

\begin{tabular}{||c|c|c|c||}
\hline \hline$W(\mathrm{~g})$ & $C_{e}(\mathrm{mg} / \mathrm{l})$ & $q_{e}(\mathrm{mg} / \mathrm{g})$ & Removal \% \\
\hline 0.25 & 14.75 & 4.10 & 41 \\
\hdashline 0.5 & 10.25 & 2.95 & 59 \\
\hdashline 1 & 5.75 & 1.92 & 77 \\
\hdashline 2 & 4 & 1.05 & 84 \\
\hline 3 & 2.50 & 0.75 & 90 \\
\hline \hline
\end{tabular}

TABLE IV: EQUILIBRIUM ISOTHERM FOR RICE HUSK AT CR (VI) CONCENTRATION $\left(C_{\mathrm{O}}=25 \mathrm{MG} / \mathrm{L}\right), \mathrm{PH}=6$

\begin{tabular}{|c|c|c|c|}
\hline \hline$W(\mathrm{~g})$ & $C e(\mathrm{mg} / \mathrm{l})$ & $q e(\mathrm{mg} / \mathrm{g})$ & Removal \% \\
\hline 0.25 & 17.50 & 3 & 30 \\
\hline 0.5 & 13.50 & 2.30 & 46 \\
\hline 1 & 9.50 & 1.55 & 62 \\
\hline 2 & 6.75 & 0.91 & 73 \\
\hline 3 & 4 & 0.70 & 84 \\
\hline
\end{tabular}

\section{B. Estimation of Adsorption Isotherm Constants for Rice Husk System}

The Langmuir, Freundlich, and the equilibrium adsorption isotherms of cadmium adsorption onto the rice husk at $25 \pm 5 \mathrm{C}^{\circ}$ are shown in Fig. 1 to Fig. 3 respectively.

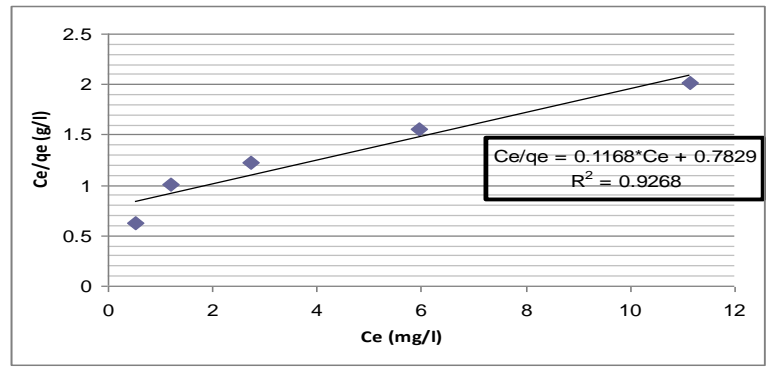

Fig. 1. Langmuir adsorption isotherm of $\mathrm{Cd}$ (II) onto rice husk at $\mathrm{pH}=6$. 


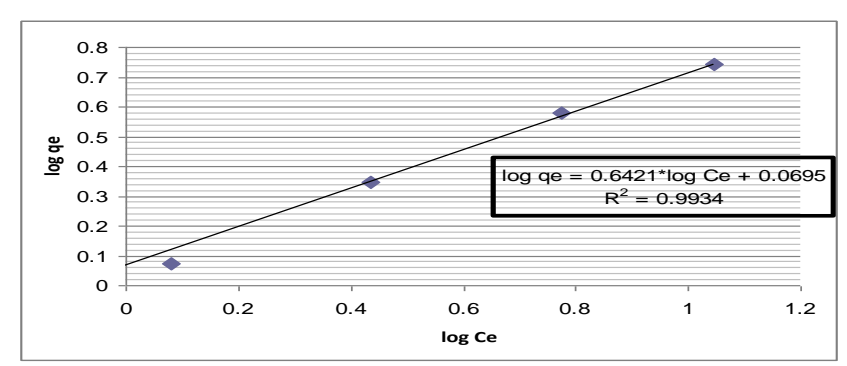

Fig. 2. Freundlich adsorption isotherm of $\mathrm{Cd}$ (II) onto rice husk at $\mathrm{pH}=6$.

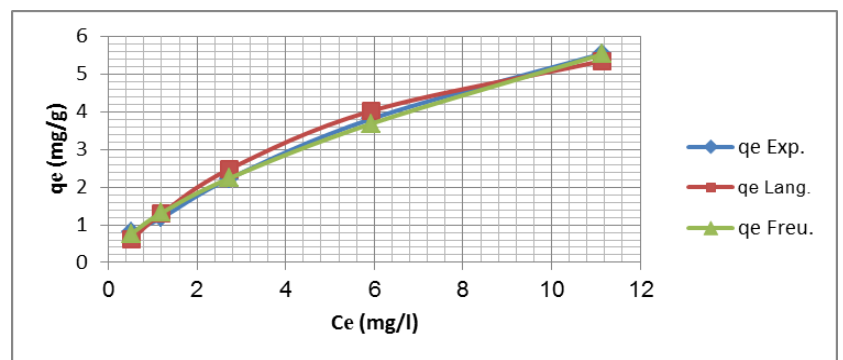

Fig. 3. Equilibrium adsorption isotherm of $\mathrm{Cd}$ (II) onto rice husk at $\mathrm{pH}=6$.

\section{Adsorption Isotherm}

Adsorption equilibrium data of $\mathrm{Cd}(\mathrm{II})$ was fitted to the Langmiur and Freundlich isotherm models. These isotherms are expressed by the following equations:

$$
\begin{gathered}
q_{e}=\frac{q_{\max } K G_{e}}{1+K G_{e}} \\
q_{e}=K_{F} C_{e}^{1 / n}
\end{gathered}
$$

where: $q_{e}$ : The amount of adsorbate adsorbed per unit mass of adsorbent at equilibrium $(\mathrm{mg} / \mathrm{g}), C_{e}$ : The equilibrium concentration in the solution $(\mathrm{mg} / \mathrm{l}), q_{\max }$ : The maximum adsorption capacity, $K$ is the adsorption equilibrium constant (rate of adsorption), $K_{F}$ is roughly an indicator of the adsorption capacity of the adsorbent which can be defined as the adsorption or distribution coefficient $\left(\mathrm{mg} / \mathrm{g}(1 / \mathrm{mg})^{1 / \mathrm{n}}\right)$ and $1 / n$ is the adsorption intensity or surface heterogeneity.

The experimental data was also correlated by both linearised Langmuir and Freundlich equations (Eq. (3) and Eq. (4)). For $\mathrm{Cd}(\mathrm{II})$ the Langmuir and Freundlich isotherm constant are summarized in Table $\mathrm{V}$ for rice husk.

TABLE V: LANGMUIR AND FREUNDLICH ISOTHERM PARAMETERS FOR CD (II)

\begin{tabular}{|c|c|c|}
\hline Model & Parameter & Value \\
\hline \multirow{4}{*}{$\begin{array}{c}\text { Langmuir } \\
\text { (eq. (3)) }\end{array}$} & $\mathrm{q}_{\max .}(\mathrm{mg} / \mathrm{g})$ & 8.5616 \\
\hline & $\mathrm{K}(1 / \mathrm{mg})$ & 0.1491 \\
\hline & $\mathrm{R}_{\mathrm{L}}$ & 0.2115 \\
\hline & $\mathrm{R}^{2}$ & 0.9268 \\
\hline \multirow{3}{*}{$\begin{array}{c}\text { Freundlich } \\
\text { (eq. (4)) }\end{array}$} & $\mathrm{K}_{\mathrm{F}}\left(\mathrm{mg} / \mathrm{g}(1 / \mathrm{mg})^{1 / \mathrm{n}}\right)$ & 1.1735 \\
\hline & $1 / \mathrm{n}$ & 0.6421 \\
\hline & $\mathrm{R}^{2}$ & 0.9934 \\
\hline
\end{tabular}
ADSORPTIONS ONTO RICE HUSK

It is clear from Fig. 1 to Fig. 3 and Table V that:
1) The present results show that the low cost adsorbent rice husk is considerably efficient for the removal of $\mathrm{Cd}(\mathrm{II})$ from its solution.

2) The value for the maximum adsorption capacity of rice husk with cadmium $(5.54) \mathrm{mg} / \mathrm{g}$.

3) The maximum removal efficiency of Cd(II) was achieved at high mass of adsorbent, while the maximum uptake was achieved at low mass of adsorbent.

4) In order to assess the different isotherms and their ability to correlate with experimental results, the coefficient of determination $\left(\mathrm{R}^{2}\right)$ was employed to ascertain the fit of each isotherm with experimental data. From Table V, the coefficient of determination values were higher for Freundlich than for Langmuir. This indicates that the Freundlich isotherm is clearly the better fitting isotherm to the experimental data with a high correlation coefficient of 0.9934 . The equilibrium isotherm for the removal of $\mathrm{Cd}(\mathrm{II})$ was of a favorable type $1 / n<1$.

\section{COLUMN EXPERIMENTS AND BREAKTHROUGH CURVES}

Continuous flow adsorption studies were conducted in glass column made of pyrex glass tube of $(0.8 \mathrm{~m})$ height and $(0.05 \mathrm{~m})$ inner diameter, a layer of glass beads was placed in the bottom of the column to ensure a uniform distribution of influent through the bed and the adsorbent bed was placed above it. The influent solution was introduced to the column through a fine stainless steel screens, fixed at the bottom of the column.

\section{A. Estimation of the Minimum Fluidization Velocity}

Minimum fluidized velocity in continuous experiments can be determined theoretically and experimentally. The calculation of theoretical value of minimum fluidized velocity can be obtained by using Equation (5). The minimum fluidized velocity is equal to $1.3525 \times 10^{-3} \mathrm{~m} / \mathrm{sec}$ which corresponds to a minimum flow rate $=9.5604 \mathrm{l} / \mathrm{hr}$. Experimentally, minimum fluidized velocity can be determined by visual observation as the lower velocity that lifts the particles and making them suspended. The experimental minimum fluidized velocity was approximately equal to the theoretical velocity. The minimum flow rate used in continuous experiments was equal to $9.6 \mathrm{l} / \mathrm{hr}$. Different flow rates of higher than the minimum were used to increase the mixing and to show its effect on the removal efficiency of Cd (II).

$U_{m}=\frac{\mu_{t}}{d_{p} \rho_{p}}\left[\sqrt{(33.7)^{2}+0.0408 \frac{\mathrm{d}_{\mathrm{p}}^{3} \rho_{t}\left(\rho_{\mathrm{p}}-\rho_{t}\right) \mathrm{g}}{\mu_{t}^{2}}}-33.7\right](5)$

where $U_{t}$ is the terminal velocity $(\mathrm{m} / \mathrm{s}), U_{m}$ is the minimum fluidized velocity $(\mathrm{m} / \mathrm{s}), d_{p}$ is the particle diameter $(\mathrm{m}), g$ is the gravitational force $\left(=9.81 \mathrm{~m} / \mathrm{s}^{2}\right), \rho_{l}$ is the density of liquid $\left(\mathrm{kg} / \mathrm{m}^{3}\right), \rho_{p}$ is the density of solid $\left(\mathrm{kg} / \mathrm{m}^{3}\right)$ and $\mu_{l}$ is the liquid viscosity (water $=1 \times 10^{-3} \mathrm{~Pa} . \mathrm{s}$ ).

\section{B. Effect of Initial Concentration}

The effects of initial concentration are illustrated in Fig. 4. 
It is clear that the time required reaching saturation decreases with the increasing of the inlet solute concentration. In the case of low initial solute concentration, the diffusion rate will take a longer time to reach saturation. It is also clear that when the influent concentration increases, the adsorption capacity increases. This is due to a high concentration difference between the bulk solution and the concentration of the solute on the solid phase. This will increase the rate of mass transfer of solute to attach a free site(s) on the solid phase of the rice husk. The driving force for adsorption is the concentrations difference between the solute on the adsorbent and in the solution. If the initial concentration is high, the saturation of the bed is faster and the slope of the breakthrough curve is higher.

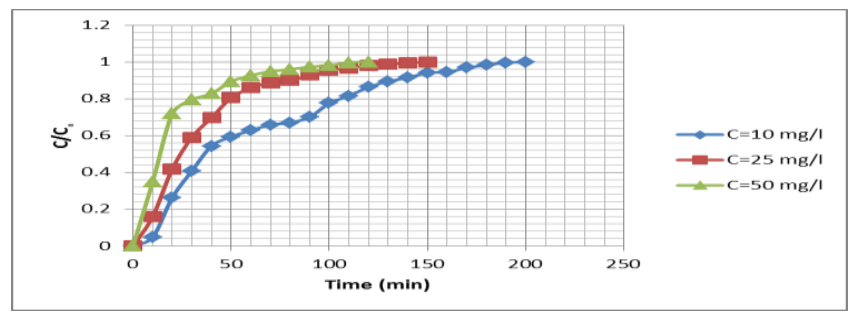

Fig. 4. The experimental breakthrough data for adsorption of $\mathrm{Cd}$ (II) onto rice husk at different initial concentrations, $\mathrm{Q}=18 \mathrm{1} / \mathrm{hr}, \mathrm{L}=0.2 \mathrm{~m}, \mathrm{pH}=6$.

\section{Effect of Adsorbent Bed Height}

Fig. 5 shows the effects of bed height on removal efficiency. It is obvious that when the bed height increases, the time to reach breakpoint increases. The increasing of bed height will provide an extra surface area for the adsorption process. This shows that at a low bed height the effluent adsorbate concentration ratio increases more rapidly than for a higher bed height. Furthermore, in a low bed height, the bed is saturated in less time. A lower bed height corresponds to lesser amount of adsorbent and weak capacity for the bed to adsorb adsorbate from solution. When the flow rate kept constant, the increasing of the bed height will increase the contact time of the solute in the bed, and these improve the solute removal efficiency.

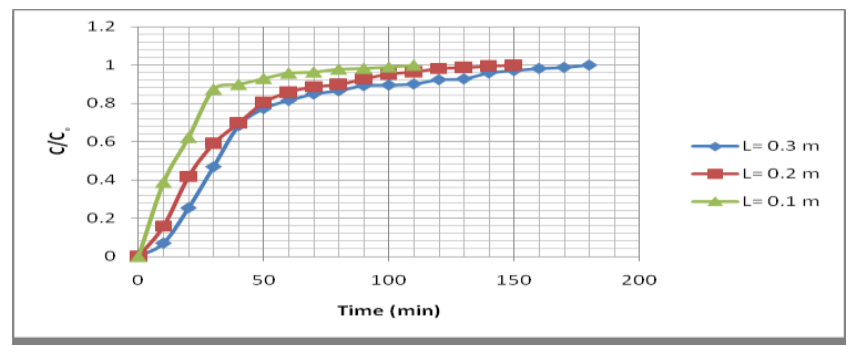

Fig. 5. The experimental breakthrough data for adsorption of Cd (II) onto rice husk at different bed depths, $\mathrm{Q}=18 \mathrm{l} / \mathrm{hr}, \mathrm{Co}_{\mathrm{o}}=25 \mathrm{mg} / \mathrm{l}, \mathrm{pH}=6$.

\section{Effect of the Solution Flow Rate}

When the flow rate increases the breakthrough curves become steeper. At a high flow rate, the adsorbate solution leaves the column before the complete equilibrium occurs due to the reduction in the contact time as shown clearly in Fig. 6. The increasing of flow rate will cause a reduction in thickness of the surface film which considered the resistance for the mass transfer. As a result of that the increasing in flow rate will increases the mass transfer rate. The increasing of flow rate leads to an additional disturbances (mixing) which makes the penetration and the passage of the adsorbate molecules through the particles and occupy a site(s) on the adsorbent easier.

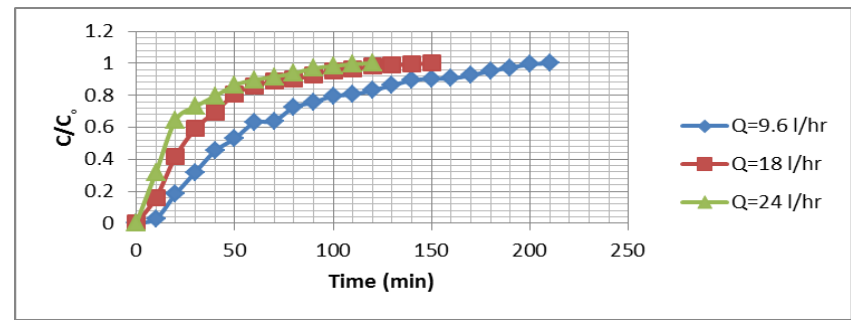

Fig. 6. The experimental breakthrough data for adsorption of $\mathrm{Cd}$ (II) onto rice husk at different flow rates, $\mathrm{L}=0.2 \mathrm{~m}, \mathrm{C}_{0}=25 \mathrm{mg} / \mathrm{l}, \mathrm{pH}=6$.

\section{E. Comparing the Results}

Two different adsorbents, namely commercial activated carbon and rice husk were used fluidized bed experiments to evaluate the adsorption performance of the rice husk as compared to commercial activated carbon as can be seen from Fig. 7 and Fig. 8.

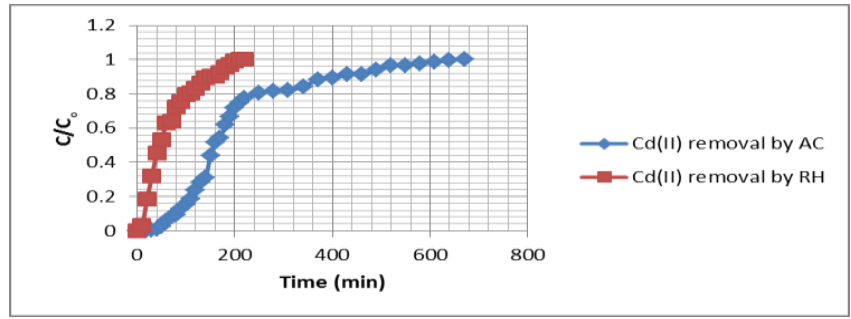

Fig. 7. The experimental breakthrough data for adsorption of $\mathrm{Cd}$ (II) onto commercial activated carbon and rice husk at $\mathrm{Q}=9.6 \mathrm{l} / \mathrm{hr}, \mathrm{L}=0.2 \mathrm{~m}, \mathrm{Co}=25$ $\mathrm{mg} / \mathrm{L}, \mathrm{pH}=6$.

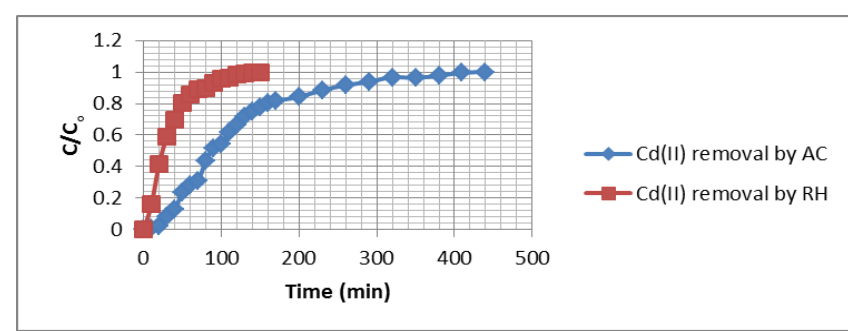

Fig. 8. The experimental breakthrough data for adsorption of Cd (II) onto commercial activated carbon and rice husk at $\mathrm{Q}=18 \mathrm{l} / \mathrm{hr}, \mathrm{L}=0.2 \mathrm{~m}, \mathrm{Co}_{\mathrm{o}}=25$ $\mathrm{mg} / \mathrm{L}, \mathrm{pH}=6$.

In fact, the commercial activated carbon has higher surface area, adsorption capacity, and higher porosity than any other adsorbent. The comparison was made with activated carbon which showed that high removal efficiencies were achieved. This can be attributed to the fact that the commercial activated carbon has higher adsorption capacity than rice husk. Difference in sorption of heavy metals by sorbent materials depends probably on the affinity of metal ions for active groups on the substrate.

\section{CONClusions}

From the obtained results, it seems that rice husk has proven to be a promising material for removal of contaminants from wastewater; it is really an efficient and economic adsorbent that is effective for the removal of 
different heavy metals pollutants from wastewater. The using of continuous fluidized bed makes the process of adsorption faster and more efficient due to increasing the adsorption surface area of the adsorbent which leads to reduce the dead zones between the particles. The results of continuous flow experiments show that, as the flow rate increases, the time required reaching saturation of adsorbent decreases. For smaller bed height, $(\mathrm{C} / \mathrm{Co})$ ratio increases more rapidly than for a higher bed height. For a higher adsorbate initial concentration, steeper breakthrough curves are obtained and break point is achieved sooner. The fluidized-beds process of activated carbon can be used effectively in the treatment of wastewater more specifically in treatment of heavy metals. Column experiments (fluidized bed system) showed that the use of rice husk instead of GAC reduces the operating time by about (66-69) \% at similar operation conditions.

\section{REFERENCES}

[1] I. Z. Cheueh, Ion Exchange Modeling of Silicotitanate Column for Chromium Removal from Arngentine Waste, Wisting house Savannah River Company, USA, 2005.

[2] D. Sud, G. Mahajan, and M. P. Kaur, "Agricultural waste material as potential adsorbent for sequestering heavy metal ions from aqueous solutions- A review," Bioresource Technol, vol. 99, pp. 6017-6027, 2008.

[3] S. Bable and T. A. Kurniawan, "Low-Cost adsorbent for heavy metals uptake for contaminated water, A review," J. Hazard. Mater, vol. 97, pp. 219-243, 2003

[4] A. G. El-Said, N. A. Badawy, and S. E. German, "Adsorption of Cadmium (II) and Mercury (II) on to natural adsorbent rice husk and ash (RHA) from aqueous solutions, study in single and binary system,' Journal of American Science, vol. 6, p. 12, 2010.

[5] A. El-Maghraby and H. A. El-Deeb., "Removal of a basic dye from aqueous solution by adsorption using rice hulls," Global NEST Journal, vol. 13, no. 1, pp. 90-98, 2011.

[6] K. F. Al-Sultani and F. A. Al-Seroury, "Characteriza tion the removal of phenol from aqueous solution in fluidized bed column by rice husk adsorbent," Research Journal of Recent Sciences, vol. 1 (ISC-2011), pp. 145-151, 2012.

[7] R. W. Gaikwad, "Removal of lead by reverse fluidization using granular activated carbon," Iranica Journal of Energy \& Environment, vol. 3, no. 4, pp. 315-320, 2012.

[8] S. Gueu, B. Yao, K. Adouby, and G. Ado, "Kinetics and thermodynamics study of lead adsorption onto activated carbons from coconut and seed hull of the palm tree," Int. J. Environ. Sci. Tech., vol. 4, pp. 1, 2007.

[9] Z. B. Yonebayashi, "Correlation and calculation of eco-toxicological materials in water using a generalized adsorption isotherm," Adsorption, vol. 4, pp. 57-62, 1999.

[10] S. Y. Mohammed, "Removal of cadmium from simulated wastewater using biosorption," M.Sc. Thesis, University of Baghdad, College of Engineering, Environmental Engineering Department, 2012.

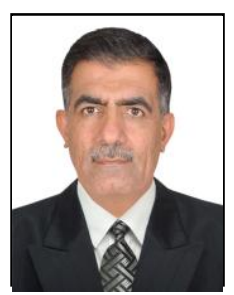

Jabbar Al-Baidhani was born in Maysan, Iraq on July 1, 1965. He received his Ph.D. degree in environmental and sanitary engineering from University of Technology, Department of Building and Construction Engineering, Environmental Engineering Branch, Baghdad, Iraq in 2003, an MSWRE and BSWRE from Baghdad University, College of Engineering, Water Resources Engineering Department, Baghdad, Iraq in 1989 and 1986. The major field of his study is in environmental engineering.

$\mathrm{He}$ is a professor of environmental engineering at the University of Babylon, Iraq. He has served as a faculty member in Engineering Faculty of Babylon University over more than 22 years. He serves nationally as a consultant engineer with national governmental offices and private concerns. He has 22 years of experience as a researcher, teacher and a supervisor in the related field of environmental engineering. He is a former head of Environmental Engineering Department of Babylon University. His current job is a teacher in Environmental Engineering Department, Faculty of Engineering, Babylon University. He has published over 30 technical papers in fields of water and environmental engineering. The last three published papers are paper of title A New Attempt of Using Crushed Plastic Solid Wastes in Water Filtration which has been published in the Journal of Civil Engineering and Architecture, USA, David Publishing Company, February, 2013, while the second paper is of title Assessment of Raw and Treated Water Quality of Main Water Treatment Plants in Babylon Govenorate, Iraq by Using Water Quality Indices that to be published in the International Journal of the Environment and Water, Dar Alanbat P.P, publisher, Manchester, UK, 2013, and the last paper which has the title "Hydraulic Characteristics of a Rectangular Weir Combined With Equal and Unequal Size Three Rectangular Bottom Openings" has been published in International Journal of Computational Research, Vol. 04, Issue, 01,USA.

Professor Al-Badhani is a member of the Iraqi Engineers Union, a member of Babylon University Consultant Engineering Bureau. Also he is a member of advisory committee for two Iraqi scientific and engineering journals. $\mathrm{He}$ participated in many examining committee of master and doctorate degrees in different Iraqi universities.

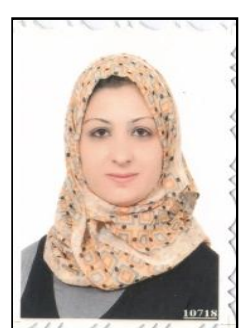

Simaa Al-Salihy was born in Babylon, Iraq in on November 12, 1989. She received her M.Sc. degree in environmental engineering from university of Babylon, Department of Civil Engineering, Environmental Engineering Branch, Babylon, Iraq in 2014, an B.Sc. degree from Babylon University, College of Engineering, Civil Engineering Department, Babylon, Iraq in 2011. The major field of her study is in environmental engineering.

She is a lecturer of environmental science at the University of Al- Qasim Green, Babylon, Iraq.

Al-Salihy is a member of the Iraqi engineers union. 